\title{
Photography: Making and Breaking Racialised Boundaries: an Essay in Reflexive, Radical, Visual Sociology.
}

\author{
by Max Farrar \\ School of Social Sciences, Leeds Metropolitan University, UK
}

\author{
Sociological Research Online, Volume 10, Issue 1, \\ < http://unw. socresonline.org.uk/10/1/farrar.html> \\ doi:10.5153/sro. 1033
}

Received: 7 Jan 2005 Accepted: 10 Mar 2005 Published: 31 Mar 2005

\section{Introduction}

1.1 Visual representation is politically charged (Shohat and Stam 1994, Hall 1997, Pickering 2001), and in beginning to think sociologically about my thirty year archive of photographs in black and multi-cultural settings (mainly in Chapeltown, Leeds, UK) I have to ask myself the question: is this work part of the problem, or part of the solution? I pose the question in this polemical form, because this essay departs somewhat from academic conventions. It seeks to capture something of the political and social context in which my photographic work has developed, alongside, but until very recently, quite separately from my sociological work. "You are either part of the problem or part of the solution!" is the Black Power slogan which has rung in my ears since the late 1960s. I see now that it is framed in terms of binary oppositions which post-structuralism insists we transcend. But the reality of black/white interactions, while they have in many cases moved beyond such simple oppositions, remain intractably confrontational in much of the public sphere. In the cinema, these binaries have sometimes been cleverly mocked. For insistence, there is a scene in the film Crocodile Dundee (Peter Fairman, 1986) which must stick in the mind of visual sociologists. Linda Kozlowski, playing a white American journalist, points her expensive camera at David Gulpilil, whose status as "the native" is produced by the absence of western clothing, thus revealing most of his black skin. He waves his hands in protest. The journalist says she fully understands the Aboriginal belief that cameras suck the souls out of native peoples. No, says Gulpilil, it's just that you have the lens cap on. Some whites laughed knowingly, as we were reminded of the accusations of ethnocentrism and racism made against social science, of our new-found awareness of the sophistication of so-called natives. We might even have applauded the script-writers (Paul Hogan, Ken Shadie and John Cornell) for exhibiting awareness that the camera is capable of reinforcing racialised boundaries between people. But some in the audience, mainly people of the African diaspora perhaps, might have been less amused. Why, they probably asked, was David Gulpilil represented as semi-naked, still fulfilling the racist, white stereotype of the Aboriginal Other?

1.2 Moments like these in the controlled space of the cinema force us to confront difference and to recognise that words, images, texts are always read in specific contexts, in diverse ways, by diverse audiences. At risk of over-simplifying, and thus re-inscribing the binary, I acknowledge that black and white readers of the images and text in this essay may well produce quite different interpretations. Probably only those readers who remain located within the radical social movements will ask the simple "solution/problem?" question directly, and for me it remains a framing question. It has shaped the position from which I have pointed my camera at all subjects, black and white, over the past thirty years. Do the people whose photos I am taking position my work as supportive of radical social change for justice and equality, or as complicit with the powerful? Simple questions like these were briefly fashionable within sociology thirty years ago, but are widely seen as crude and/or irrelevant today. In this essay I offer circumspect answers which have changed over the years. Whereas many of the black subjects of my early photos demonstrated to me, and to my camera, that they considered my presence intrusive and unwelcome, signifying the neo-colonial power structures of the dominant culture in the UK, as time went by more and more black people, and my white children, provided opportunities to enter into 'black' social spheres with the purpose of recording it photographically. I conceptualise this process as one of establishing, and contesting (in this case using photography), the racialised boundaries between white and non-white peoples that are an inevitable product of a society in which whites have, historically, achieved, and sought to maintain, dominance over black people. The photos might go further, I will argue, in inciting an unpredictable range of responses which go beyond the 'anti-racist' intent in their staging. Mostly, I hope that the photos of people, in particular their faces, incite in the viewer an ethic of responsibility for the Other. I make one other small claim for these photographs: that they provide a visual record of normally unrecognised aspects of the lives of people living in one of the typical low-income, multi-cultural, inner city areas of Britain over the past 30 years. These are the photos which the mass media hardly circulate, and which are therefore not widely available. In setting them out in all their ordinariness, these photos aim to 
1.3 The paper engages in a reflexive examination of the social and political settings in which this work has been done. My account draws partly on the changing configuration of black politics over the past thirty years and partly on the development of my own, and my family's social relationships in this neighbourhood. Sociologically, I draw on Miles' work on racialisation, Lefebvre's on representation, and Levinas' phenomenology of the face. Since I take the view that sociological analysis cannot be separated from the embodied, value-laden and emotional practice of the sociologist, this essay is presented chronologically and biographically. Since I am also committed to a style of sociology which is accessible outside the confines of the academy, journalistic headlines will appear from time to time. This essay might also be read as an adjunct to the methodology section of my book on Chapeltown (Farrar 2002b). By this I mean to suggest that the methodology employed in writing a sociological account of this neighbourhood over a long period of time was excessively structured by the requirements of academic, textual sociology: reduction of affect in pursuit of the semblance of objectivity, and the absence of visual materials. This essay, and these photos, provide a welcome opportunity to personalise, and contextualise, my academic work. It also aims to demonstrate the usefulness of a specifically visual sociology not as a mere adjunct to textual sociology but as a source of new understandings of the social world.

1.4 This essay does not start from a specific research question. It starts from the Black Power question which preceded my entry into sociology, and which caused me to abandon sociology for twenty years or so from 1974. But since this is an academic journal, readers are entitled to expect a reasonably clear formulation of my aims. These are:

1. To practise sociological reflexivity, not in the cold sense of critical reflection, but in the hot sense of acknowledging the intensely emotional state in which I, at least, attempt to make sense of and change the world, and intending to reveal a little of how this emotional work infuses and shapes my sociological and political work. (A subsidiary aim here is to seek to give value to a form of writing within academic sociology which acknowledges, in the text, the personal and emotional struggle that is at the heart of the sociological project.)

2. To provide a historically specific, developmental account of the interaction between my social context and my photographic work, with a specific interrogation of the political effects of these photos. (A short-hand for this is to demonstrate the changing meanings of photography over time. More specifically, I aim to show how the polemically-charged meanings which initially impelled my photography shifted as time went by, resulting in new subject matter being sought out, producing different types of photos with different intended effects.)

3. To test the possible relationships between sociological theory and photography - relationships which I now recognise have been developed over twenty years or more within the International Visual Sociology Association, but which are quite new to me.

1.5 Given these aims, readers will understand why theory intrudes mainly in the last part of this essay. Because of the essay's chronological narrative, and my recent return to theory, it is largely saved to the end of my story.

\section{The 1970s: Politics is Personal}

2.1 Like some others of my generation, I was radicalised by the black civil rights movement in the USA, opposition in the USA and Europe to the war against the Viet Cong, and the radical movements (including feminism and gay liberation) that emerged in the early 1970s. From the mid-1960s onwards, race (I had not yet learned the need for scare quotes) seemed to me to be at the heart of political and cultural struggle. The record is clear that there were significant political movements among Britain's black population from the mid-1960s (Sivanandan 1982, Fryer 1984, Ramdin 1987). These were discussed each month from the late 1960s in the magazine Race Today and the journal Race and Class. But the books in my collection on the radical politics of that era make no reference to black politics in Britain (Cockburn and Blackburn 1969, Crick and Robson 1970, Nuttall 1970, Widgery 1976). Cohn-Bendit (1968) says nothing about political movements among black people in France, and Buckman (1970) and Caute (1988) have sections on Black Power in the USA, but no reference to black politics in the UK. Yet this politics was visible and audible. Schoolboys like me were at Speakers' Corner in Hyde Park in 1967 listening to Roy Sawh and Obi Egbuna, scintillating advocates of Black Power, and one Sunday in the spring of 1971, in my final undergraduate year, I looked out of my window in Chapeltown and saw a demonstration of black people marching past. I followed it, at a cautious distance, and applauded the militant speeches from the back of the Jubilee Hall. As a libertarian Marxist student I had begun to recognise the significance of the autonomous black and feminist movements for a politics relevant to the late Twentieth Century, and expressions such as the one used above about neo-colonial white power structures were beginning to form themselves in my mind. Recalling the gory history of British imperialism, reminding us that the problem was a 'white' one and that white power over black people did not disappear when the British de-colonised, the concept seemed highly 
relevant. It functioned politically as a bulwark both against both the racist elements in the major political parties in the UK, and against the optimism of the liberal establishment then forming what became known as the 'race relations industry'. No-one in my sociology department had any interest in this field and John Rex's sociological interventions $(1967,1970)$ were the only UK 'race' sociology I found. Somehow they could not match up to Stokely Carmichael's (1969) Black Power and Eldridge Cleaver's (1969) Soul on Ice. Nevertheless, Rex's work, combined with the US political analysts of race, seemed like a basis for graduate study of Chapeltown.

2.2 Chapeltown is known in the city of Leeds as the black 'ghetto'. Parts of the area do have a high density of people of Caribbean origin, while other parts have a high density of people who originated in South Asia. But, taken as a whole, this area is 40\% white (Farrar 2002bp. 23). Chapeltown News (1972 - 1977) was the monthly newspaper of the Chapeltown Community Association, a campaigning multi-cultural group led by middle-class whites like myself. As a grant-aided $\mathrm{PhD}$ student with no effective supervision, I had the time to write much of the offset printed, folded A3 newspaper and, after a short introduction from a friend with his own dark-room, I began to take and print many of the photos that accompanied our typewritten and Letrasetted articles. (I abandoned the thesis to dedicate more time to work like that.) Viewed today, the Chapeltown News photos demonstrate the social and political distance between me as a white photographer and the radical black subjects of the photos. Photo 1, using a Pentax Spotmatic with a 55 $\mathrm{mm}$ lens (the only one I had) shows the British/Jamaican poet Linton Kwesi Johnson reading at a cultural event organised by the West Indian Afro-Brotherhood in June 1974.

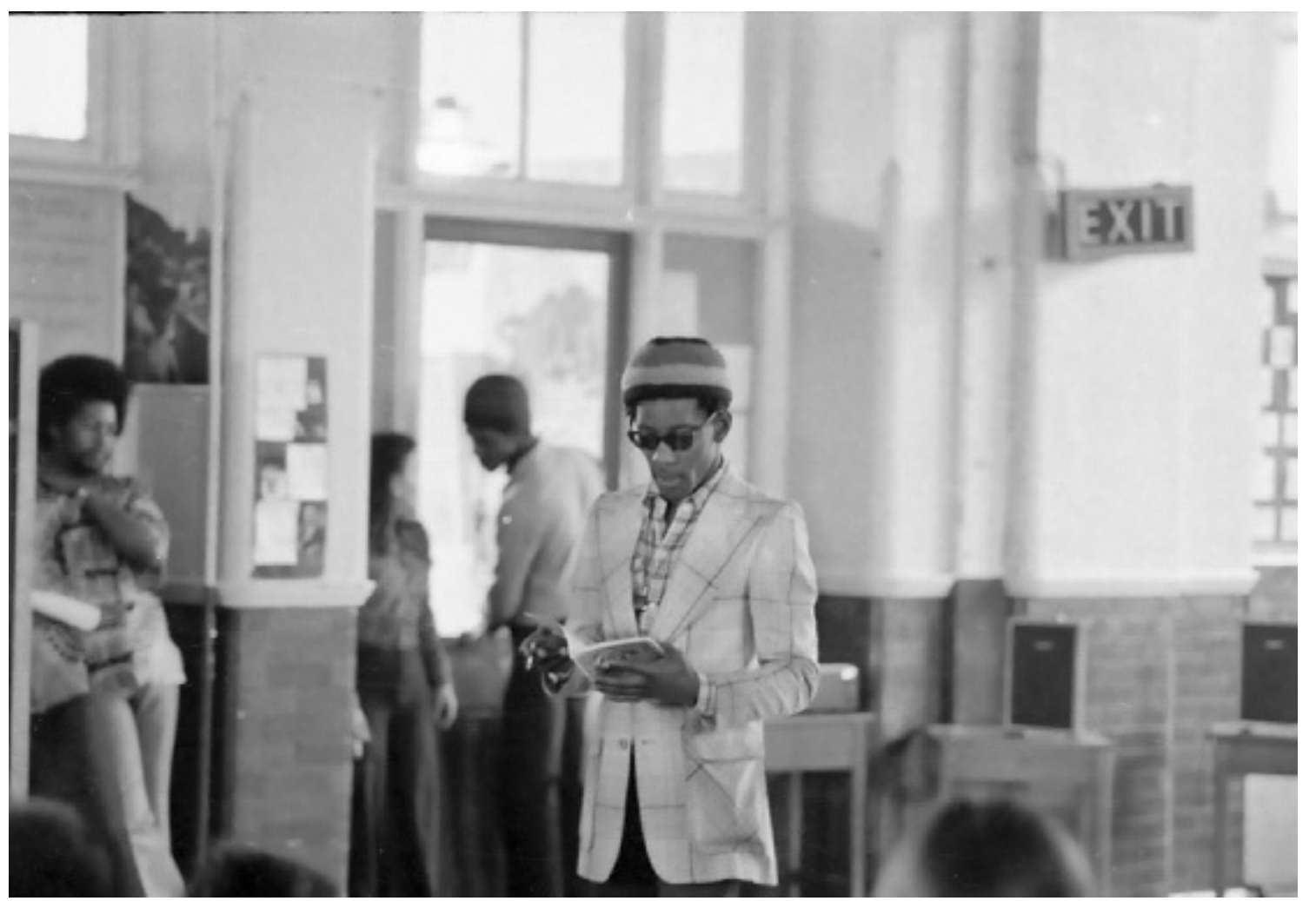

Photo 1. The poet Linton Kwesi Johnson, at the Grounding event in Cowper Street School, June 1974

I vividly recall the discomfort I felt as I stood to the side of the audience, too far away from the poet for an effective photo. The Brotherhood (which included women among its leading members) had made it very clear to me that they rejected my professed support for black autonomy, seeing me (at best) as a white missionary and, at worst, and in the words of one of their members, a "white devil". They tolerated my presence simply because they wanted coverage for the event in Chapeltown News. Figure 1 shows a page of the subsequent report. 


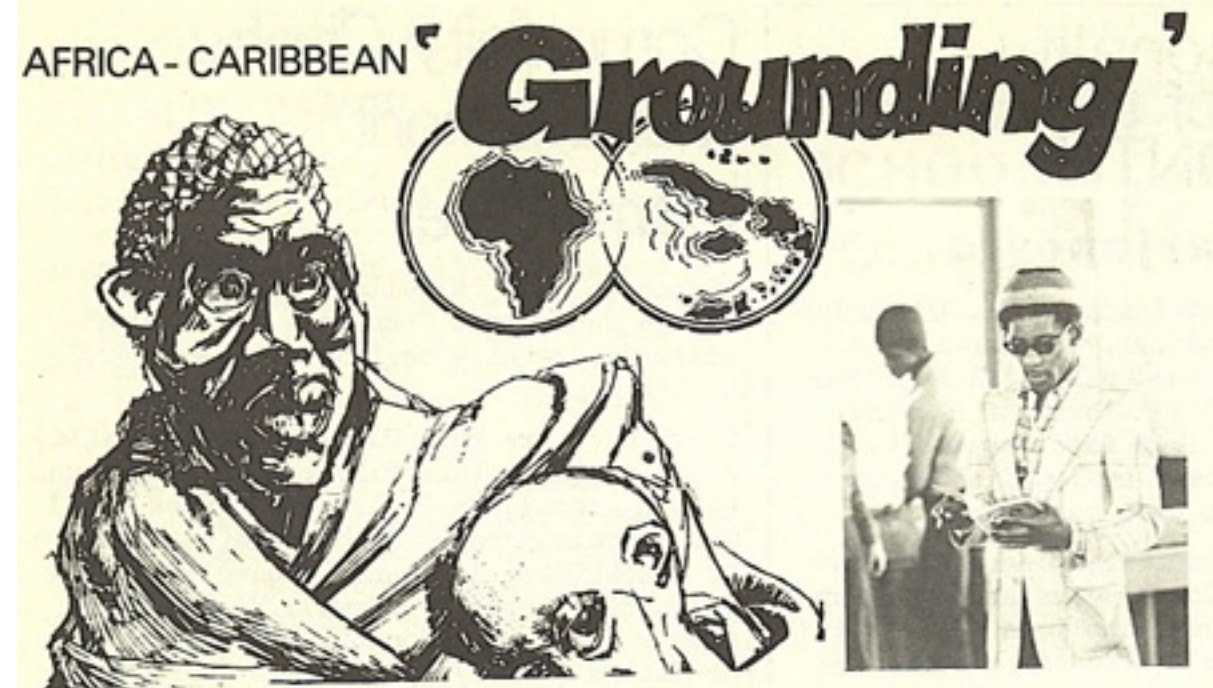

Lynton Kwesi Johnso from his book 'Voic living and the dead from Race Today, 18 Cross Road, London

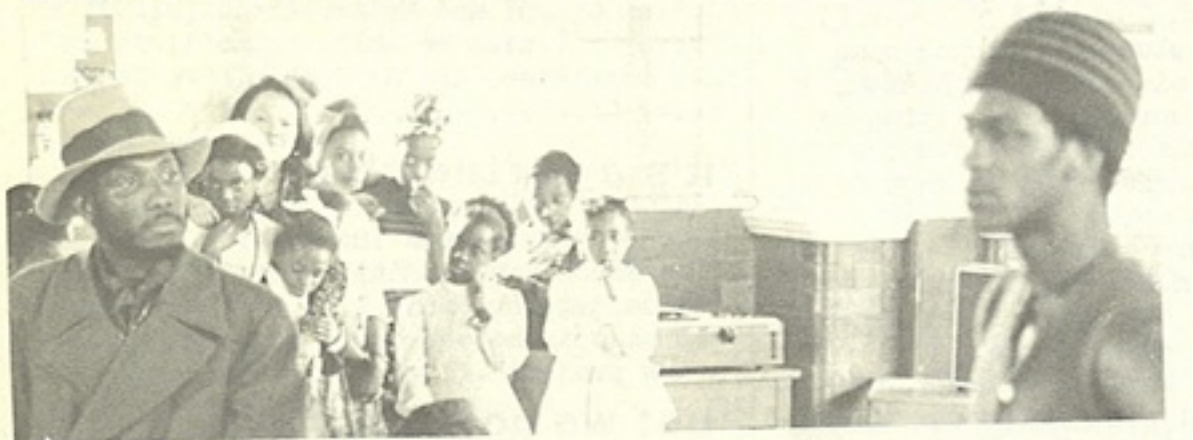

Sunday 2nd May was a occasion for the deve West Indian community For four hours a pack Earl Cowper Middle Sc entertained by a succ dances, poetry and th med by young people o unity.

But this wasn't an or ural gecasion". All ances had a unifying that there is a strug Black people resistin in all its forms, whe the Special Patrol Gr Tom, the Church or ou mistreating themselve other. Black people roots in Africa, find identity, shouting th freedom, and preparin

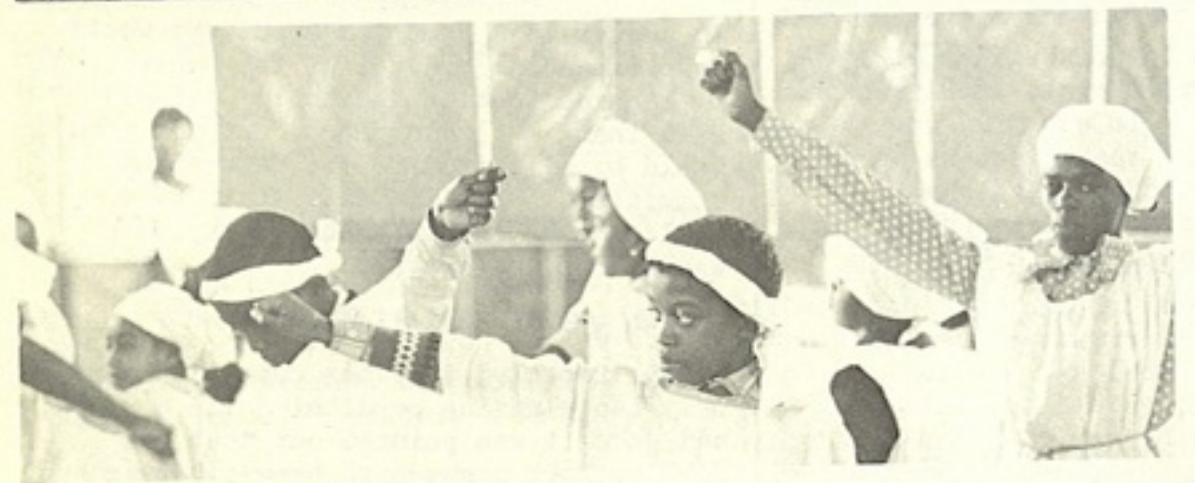

To emphasise the fact strugele of West Indi is the aame struggle our sisters and broth out the world, we hea of Iynton Kwesi Johns in London) and speech Brother Roger of the ation Committee and $f$

Beech of the United. Association.

A screen calling for armies fighting for. of Guine-Bissau, $\mathrm{Moz}$ Angola was the fitti the entire performan

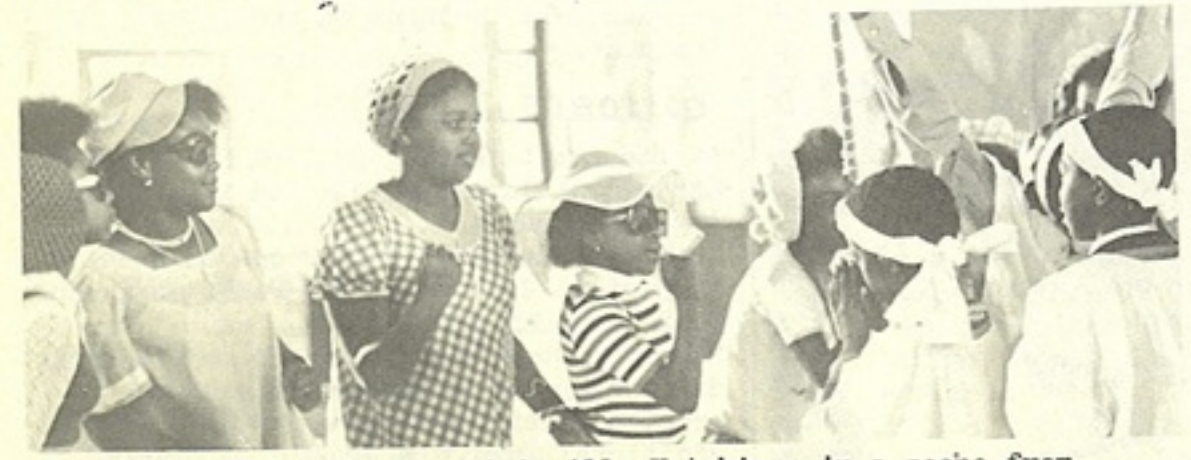

Our photos can't do beauty of the Saturd Ann Stewart, Sandra Hendrikson, Marilyn Hunkins, Patricia Co Quailey, Beverley F1 Grierson, Sonia Walt Monish, Caron Skeete Stapleton, Tracey St Robinson, Alec Archi Robinson, Susie and Joan and Synthia Flc

Top; Errol Imrhu Caesar and Orville Hutchings in a scehe from Errol's play ' So What If They Diet. Bottom- the Saturday School

Figure 1. Chapeltown News (June 1974) with cropped photo of Linton Kwesi Johnson

We cropped the pictures, for standard journalistic reasons, and they give the false impression that I was close to the action. Like every other form of discourse, photography frames its events and presents partial and situated accounts. Photo 2 shows the demonstration held outside the Leeds Crown Court (June 1976) in support of eleven black youths and me who were accused of riot. 


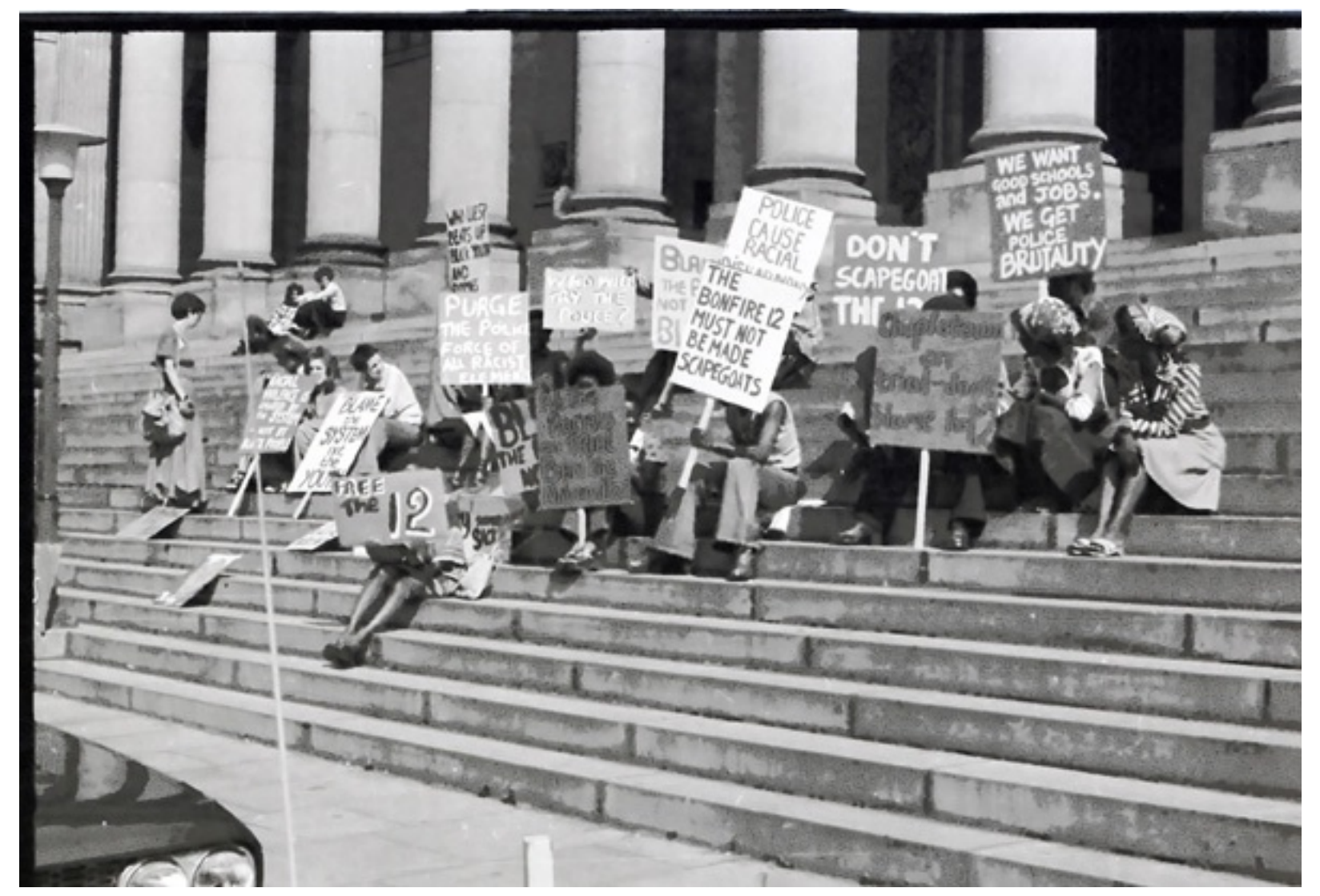

Photo 2. Demonstration in support of the Bonfire Night 12, Leeds Crown Court, June 1976

(This was the first uprising, as we called it, of black youth in the UK (Farrar 1981, Farrar 2002b pp. 218229). (Linton Kwesi Johnson called similar events in 1981 'De Great Insohreckshan' (Johnson 2002 p. 60). (Photo 3, taken in Leeds in November 1995, is part tribute to the work of this extraordinary poet and political activist, part marker of the changes and continuity in his dress style, and part testimony to the pleasure I have in returning to the same subject, in much friendlier circumstances, many years after the first photographic encounter.) 


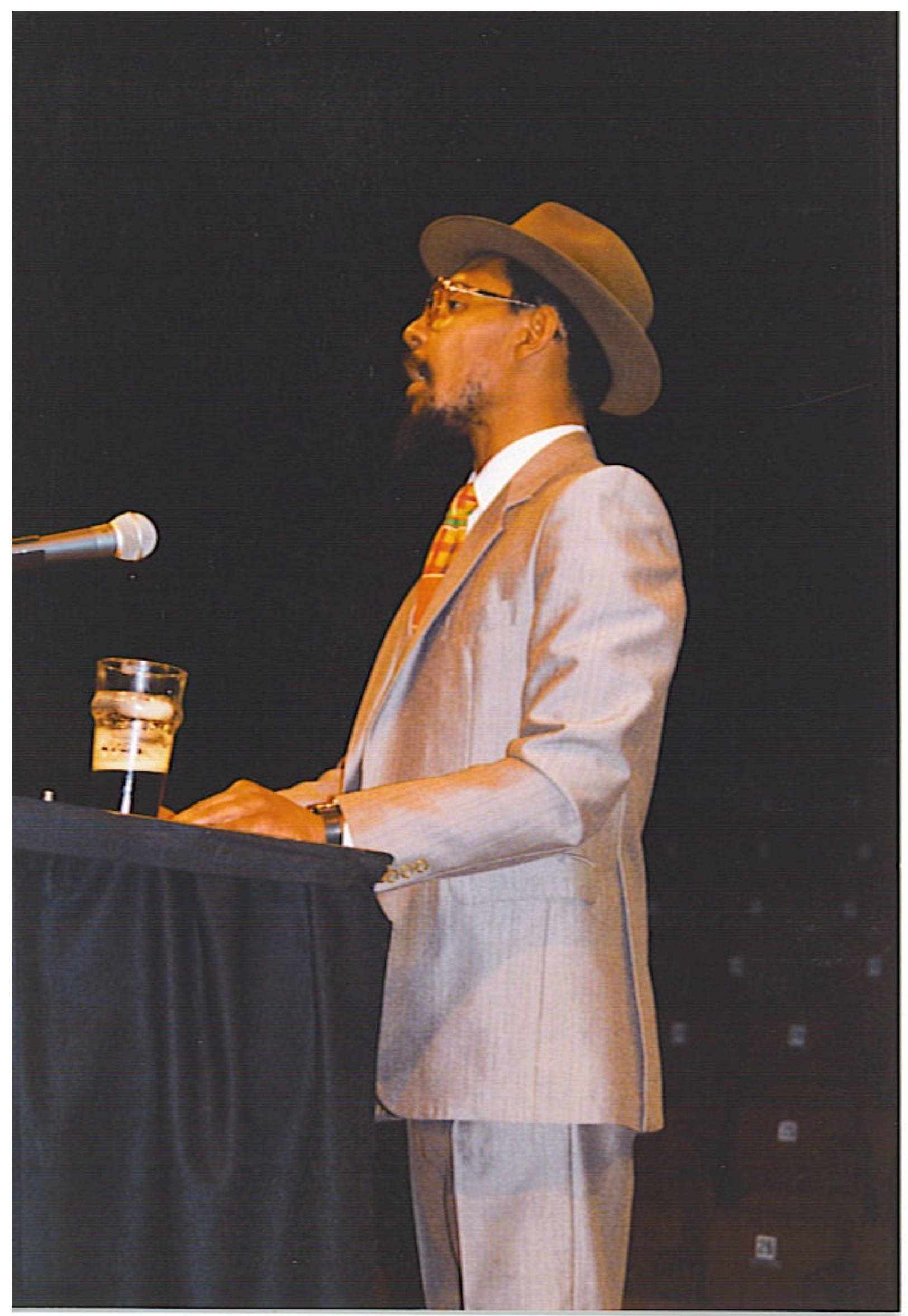

Photo 3. Linton Kwesi Johnson at West Yorkshire Playhouse, Leeds, November 1995

Despite Chapeltown News campaigning in support of the youth, and some of the white radicals in our group helping make the placards, my social and political distance is again revealed in Photo 2. Young blacks, seeing a white man with a camera, turn their faces away or hide behind placards. By the end of the trial, which in my case had been based on the more radical passages in Chapeltown News, used to justify the prosecution's claim that I had incited the affray, some solidarity had been forged, and the two Rastafarian defendants pictured (July 1976) in Figure 2 were more than willing to be interviewed by me for a later issue 

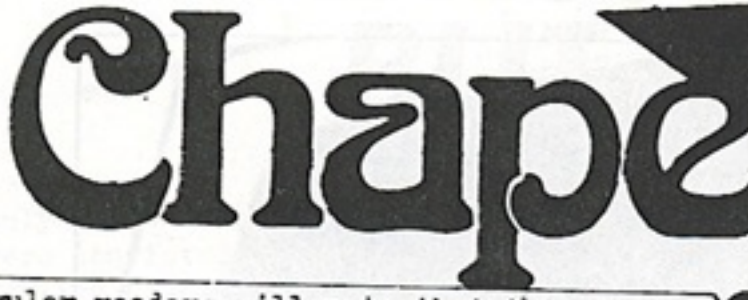

Number 37 August 1976

Regular readers will note that this 1sgue is different from others. Instead of the usual mixture of stories, this issue is much shorter and is devoted to one topic. We hope to be back to normal in October so long as we can ralse enough money to

keep going. PLAASE RUSH YOUR DONATIONS TO:
$\boldsymbol{S}_{p}$ Chapeltown News Collective, c/o Community Centre, Reginald Terrace, Leeds 7

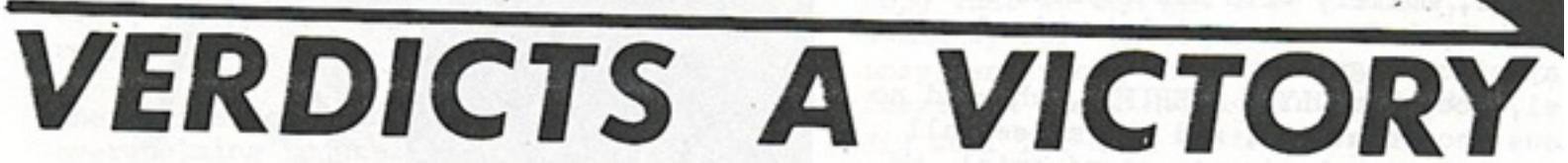

The Bonfire Night Trial finally ended on 11 th July. It will go down as a turning point in the history of Chapelt,

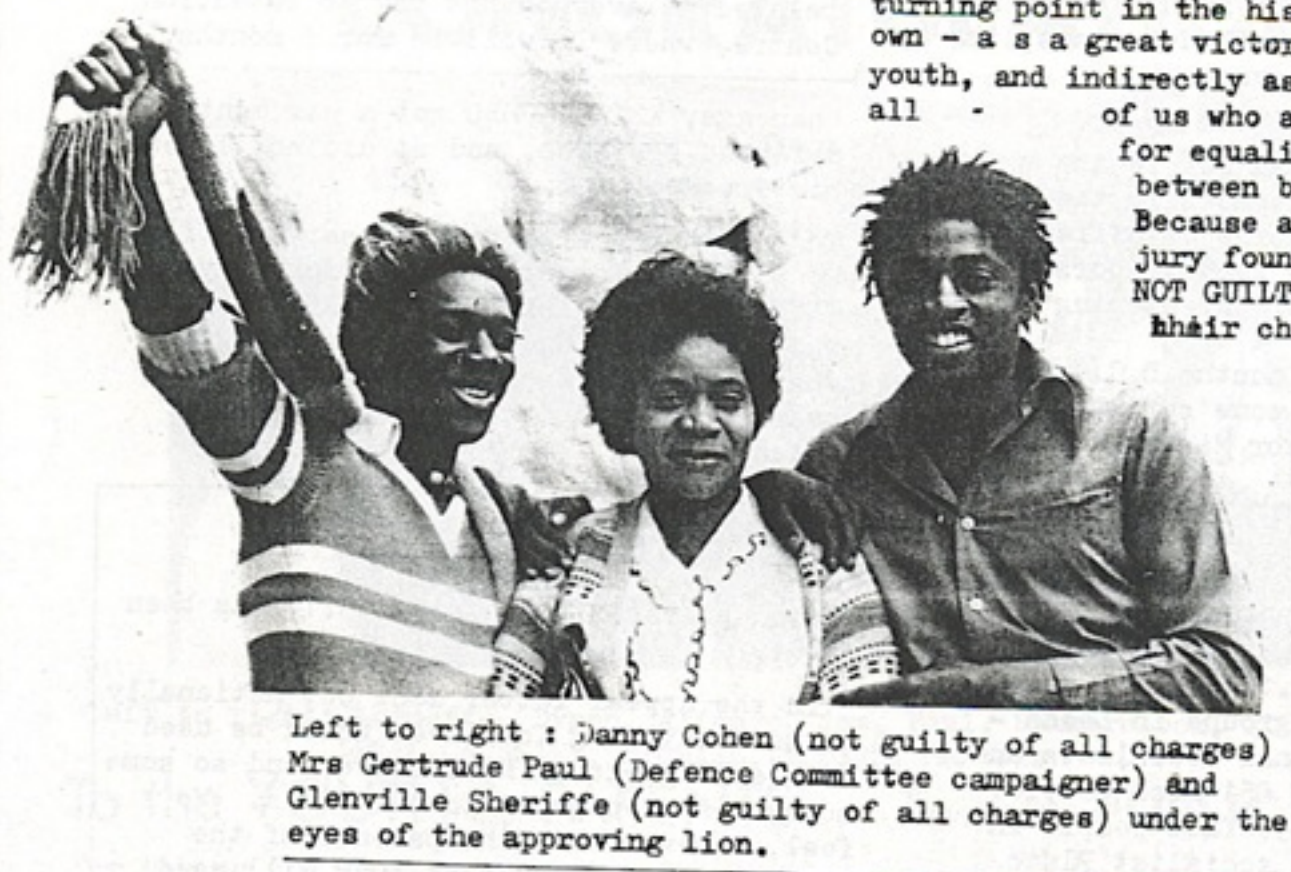

At the end of a month of

listening to the evidence the jury

found:

\begin{tabular}{|c|c|}
\hline GLENVILLE SHERTFF & NOT GUILTY of alits \\
\hline MAX FARRAR & NOT GUILTY $" n$ \\
\hline DANNY COHEN & NOT GUILTY " " \\
\hline DEREK CROSSLEY & NOT GUILTY " " \\
\hline URI MAURICE & $\begin{array}{l}\text { NOT GUILTY of the } \\
\text { only charge agains } \\
\text { him. }\end{array}$ \\
\hline
\end{tabular}

\section{but some convictions sre praE 2 :}

\section{HENRY GREY}

MICHEAL WALTERS

ON THE CEARGES RETLATING TO BONFIRE NIGET THE JURY ACQUITTED ON TWENTYONE OUT OF TWENTY-FIVE :!!

Figure 2. Chapeltown News, August 1976, Photo L-R: Clyde Sheriffe, Mrs Gertrude Paul, Danny Cohen, outside Leeds Town Hall

But hostility towards me by the most militant of the members of the West Indian Afro Brotherhood remained intense. When our (multi-ethnic) group decided to hand over control of Chapeltown News to this grouping, I was excluded from the new editorial collective. 
2.3 At the time, I saw this in personal, and political, terms. My neutral prose does not convey the pain. One slogan of the radical libertarian movement of the time was 'The personal is political' (Farrar 1989). This section of the essay is headed 'politics is personal' because politics was traumatic when black militants repeatedly confronted me with my shortcomings. When bail was rescinded during the lead-in to the trial, our daughter had just been born and I contemplated several years in prison without seeing her. During the trial, when food was brought to the cells for the black defendants only, my dream of inter-'racial' accord seemed futile. Politically, I was able to accept the exclusion: ideologically I supported the black autonomist position of the Race Today Alliance, inspired by the writings and practice of the Trinidadian Marxist CLR James (see, for example, James et. al. 1958, Buhle 1988). Personally, it was devastating.

2.4 Thinking about this sociologically many years later, I see the process of racialisation at work. Robert Miles has defined racialisation as:

those instances where social relations between people have been structured by the signification of human biological characteristics in such a way as to define and construct differentiated social collectivities (Miles 1989 p. 75)

2.5 The role of photography in the construction and sedimentation of differences in the physical appearance and cultural mores of the various populations of the world cannot be overemphasised. The photograph, massively circulated in magazines and newspapers in the latter part of the Nineteenth Century, 'proved' the ideas circulated by the so-called scientists of the earlier part of the century that 'races' were distinct and could be ordered in a hierarchy of human value. Just as I might have been accused (probably with some justification) of 'racialising' the black militants, constructing them as essentially different on the basis of their phenotype, they were doing the same to me. (Sociology may rationalise, but it does not overcome the emotional experience.) The concept of racialisation is one of the most powerful we have in social analysis. (Murji and Solomos 2005) It allows us to explicate the bad faith at the heart of racism today: the deliberate imposition of an assumption of difference and inferiority based simply on skin colour and other biologically insignificant, genetically determined body features, in the full knowledge that these are biological epiphenomena. Boundaries are erected and physical and emotional power is exerted on the basis of these systems of signs; racialised barriers are among the most intractable of all. For visual sociologists, racialisation is a valuable conceptual tool because of the attention it pays to signs. Since each photograph is a cluster of signs, those which are read as 'racial' have to be given careful technical and political consideration by the photographer. Technically, issues such as how light is refracted on dark skin become political problems when dark faces are made invisible by the photographer's (or printer's) incompetence. Racialisation has taken place when photographs are used by the viewer as evidence of the inferiority of non-white populations. (By extension, the absence of black people in interior and exterior scenes in the film Notting Hill (Roger Michel, 1999), set in the area of London which is home to most of the capital's citizens of Trinidadian and Barbadian heritage, could be thought of as racialisation by exclusion.)

\section{The 1980s: Personal Politics}

3.1 Decades are usually arbitrarily set by journalists as devices which serve as turning points in the narrating the history of the present, but in my case 1980 was a turning point because I got a job as an advice worker in the Harehills and Chapeltown Law Centre. Now entirely divorced from sociology, but theoretically informed by the autonomist Marxist politics of Big Flame (Howell 1981, Farrar 1989), the position from which I took photographs in the 1970s was that of a white political militant, attempting to use the photos to promote counter-hegemonic discourses alongside the campaigning groups in the multi-ethnic inner-city. This situation not only framed the photos I took, but it positioned their reception. In so far as militant black people felt that my photographs were likely to enhance their independent political practice, I might be tolerated. But that was a rare occurrence during the 1970s. (The expressly political significance of this situation is revealed by the fact that my role as a photographer within the Leeds West Indian Carnival, conceived by its initiator as 'time-off' from militancy (Connor and Farrar 2004), was much more easily established, with black people inviting me to photograph them from the mid-1970s onwards.) Working at the Law Centre, where photographs were needed to support legal cases and to illustrate our annual reports, provided a completely different context for the production of photographs. It also changed the emotional context in which I was working. More intimate relationships were formed among the black, Asian and white workers at the Centre, which resulted in me being invited to photograph their family events, such as Baptisms, children's parties or funerals. Being required to take photos in support of cases the Law Centre was running on behalf of particular clients was to be placed in a situation in which the subjects of the photos actively welcome the presence of the camera and, even in cases where the issue is emotionally charged (such as the intended deportation of a family member), positive emotions are circulating as the photograph is being taken. In all these situations, racialised difference ceases to operate with its customary force, as the photographer is given permission to enter the private, sometimes domestic, spaces occupied by the subjects. The 'legal' photographs were, like the earlier 'political' photos, framed with the intention of 
shifting the discourse in favour of the marginalised and disadvantaged. They were staged with the aim of invoking the sympathy of the viewer (magistrates, judges etc), using framing devices quite similar to those used in politically-motivated photography. But, because the emotional setting was quite different for me in the 1980s compared to the 1970s, it became possible to close up the distance between me and the subjects, both physically and symbolically. (Still possessing no zoom lens, the question of actual, physical distance was acute.) Photo 4 (Mohammed Iltaf and family, 1986, at home)

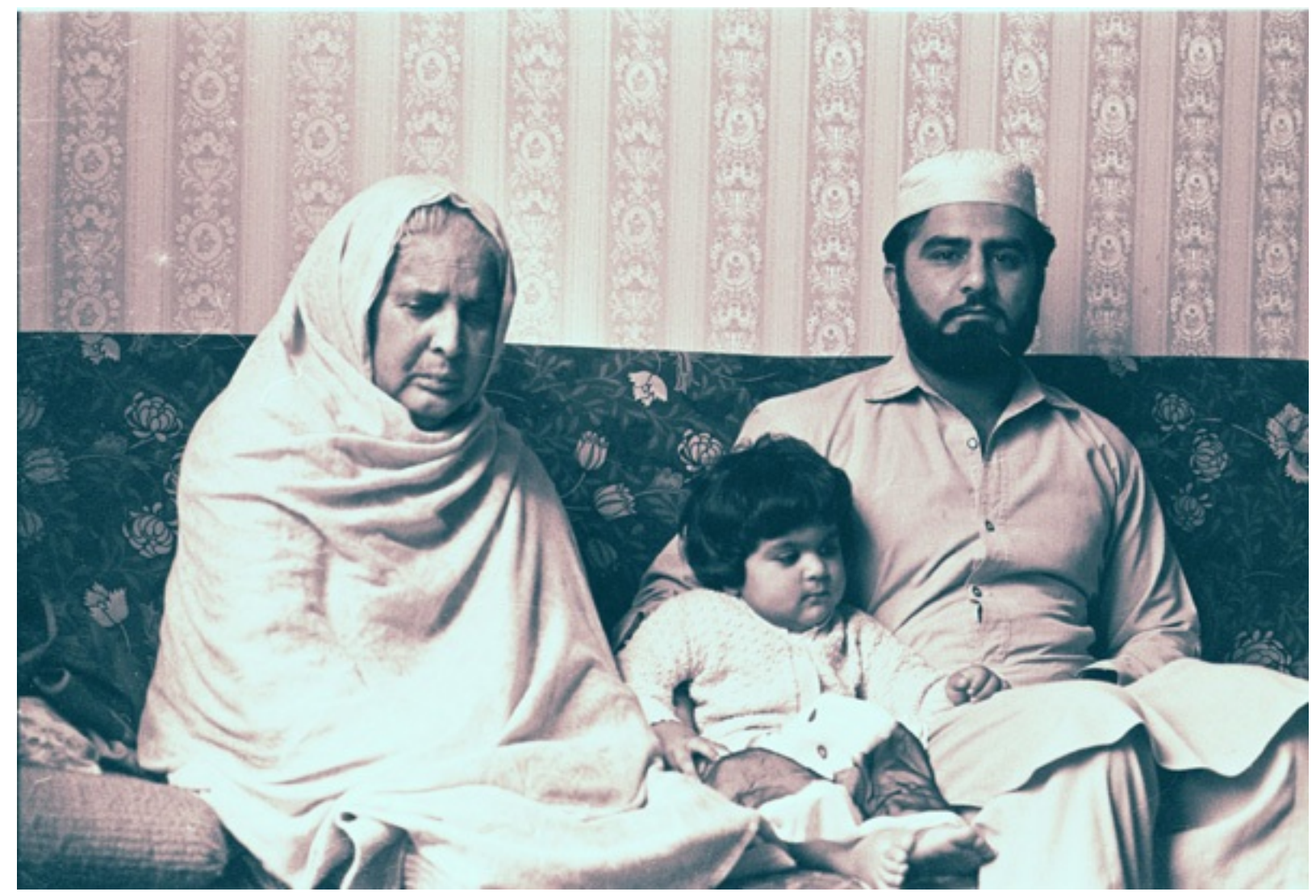

Photo 4. Mohammed Iltaf with his mother and his child, at home, 1986

and Figure 3 (from the Harehills and Chapeltown Law Centre Report for 1982-3) are examples of these 'legal' photos, taken to support cases and campaigns against deportation in the early 1980s. Figure 4 indicates that my local political photography and writing did not cease. 


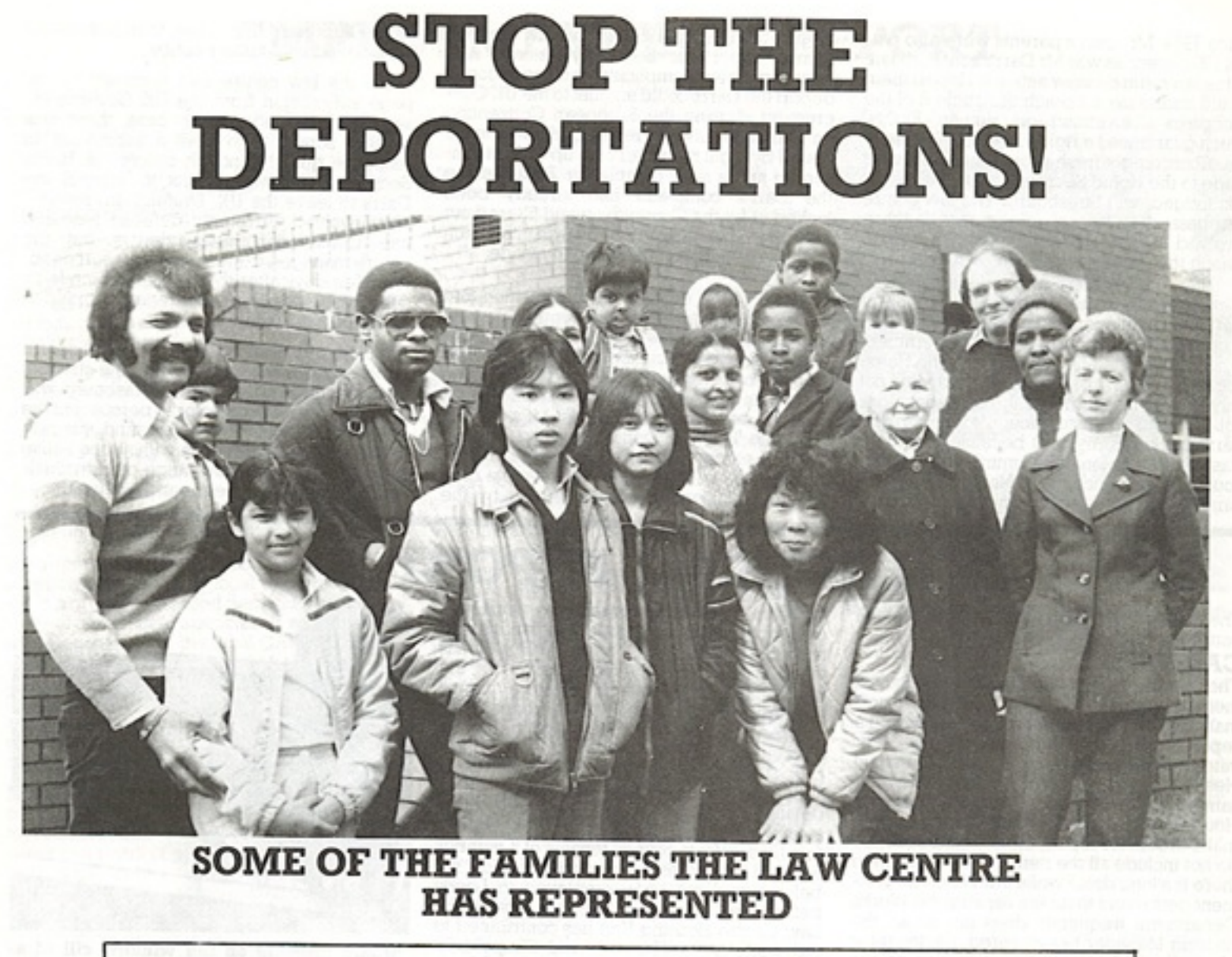

Figure 3. People threatened with deportation, represented by the Harehills and Chapeltown Law Centre, Leeds, 1982 


\section{Police on the rampage...}

First the attack the Andersons...

On Friday 16th October at about $7.30 \mathrm{pen}, \mathrm{Mrs}$ Wi. nifred Anderson of 71 Gathorne Terrace was sitting in her back room, when her daughter in-1aw rushed into the room and told her that two men werw holding Patsy outside. Mrs Anderson ran out of the house and asked the men what they wanted Patsy for. They said they wanted to talk to her. Mrs Anderson asked, "Why are you dragging her aside"? and they told her that they'd tell her once Patsy got in the car. Finally, Patsy struggled free and Mrs Andersod told her to run ins side. Mrs Anderson followed and locked the door behind her.

The men were not in uni form and at no time did they say who they were or show any identificat tion.

At about $11 \mathrm{pm}$ the same night, Mrs Anderson was upstairs in her room and saw two cars speed down the road and stop outside her house, she recognized two of the men

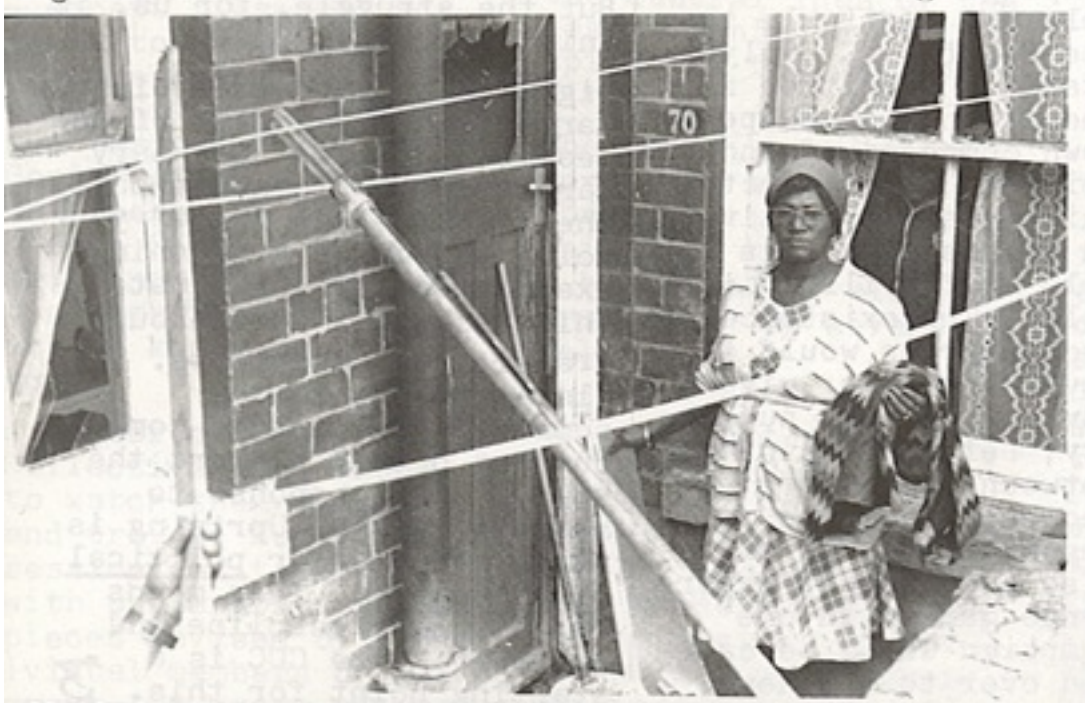

Mrs Anderson, two broken windows, broken door and mop used for cleaning Junior's blood off the hall floor to take Patsy oarlier. "They oped the car door, ran on the step and grabbed Paul- four men got him. Paul ran in and they followed. There was a struggle and one of their Walkietalkies dropped.I told them to get out and they's said they wanted the walkie-talkie and their glasses, so I passed then through the letter box".

At this time there were Police at the back and front of the house.

The following morning(Sìturday October 17 th), Mrs Anderson was outside washing the back yard. She saw a crowd of Police outside her house, some were carrying riot shield and batons. She presumed they stayed there all night. They ran through the gate and one shouted, "Nigger, move out of the way". Mrs Anderson ran upstairs to warn the children.

By the time I came down, they were in - They bust the window and the back door. I don't know how they held back the dogs, one off these dogs is really bad. They ran through the

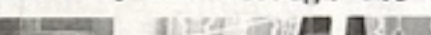

as the ones who had tried

house and bust down the front room door which I keep locked. Three or

four dragged Danovan down the stairs, they beat him with truncheons and held him on the floor with their feet in his back. They pulled Junior by his locks and dragged him out, half naked, in only his underpants and vest - they kicked him in his ribs shouting "You black nigger". (There was broken glass on the ground from the window they smashed) They dragged him out and the bottom of his feet got cut up. Some of them shoved Paul down the stairs, they beat him in his head and his head was bleeding. Patsy was in the bathroom, they rushed in and shouted, "You Bastard,get out, get out". One of them said, "Leave her alone, I want her". They pulled her by her feet down the stairs and pushed her into the meat van. They broke into my bedroom and searched under my bed - in the wardrobes and in the draws. I don't know what they were looking for"

Lindsey Hunter, Paul's girl friend, and Pauline

Jeffers had spent the night at the house, and were upstairs in the attic. "The Police drag the two girls out in their nighties, and took all six to the Chapeltown Police station".

We asked Mrs Anredson why she thought the Police had raided her house. She said: "Four weeks ago when Patsy was at the gaiety there was some trouble, some blacks had beaten up a white man. The Police held five people and Patsy's name was called. Paul had been in some trouble when he was younger. If they'd come peacefully Cont PS $\rightarrow$

Figure 4. Come-Unity News, December 1981, police raid on black family home, photo of Mrs A

A small multi-ethnic group of us formed the 'Come-Unity Collective' in 1981 and Figure 4 includes my photos and text in support of a black family who had been subjected to a particularly brutal police raid (Come-Unity News, December 1981). While we were unable to alter the fate of the defendants, one of the results of this journalism was to forge a relationship between me and members of that " $A$ " family which has endured, and led to many other photographs, in happier circumstances (for example, Photo 5, Leeds Register Office, October 1995). 


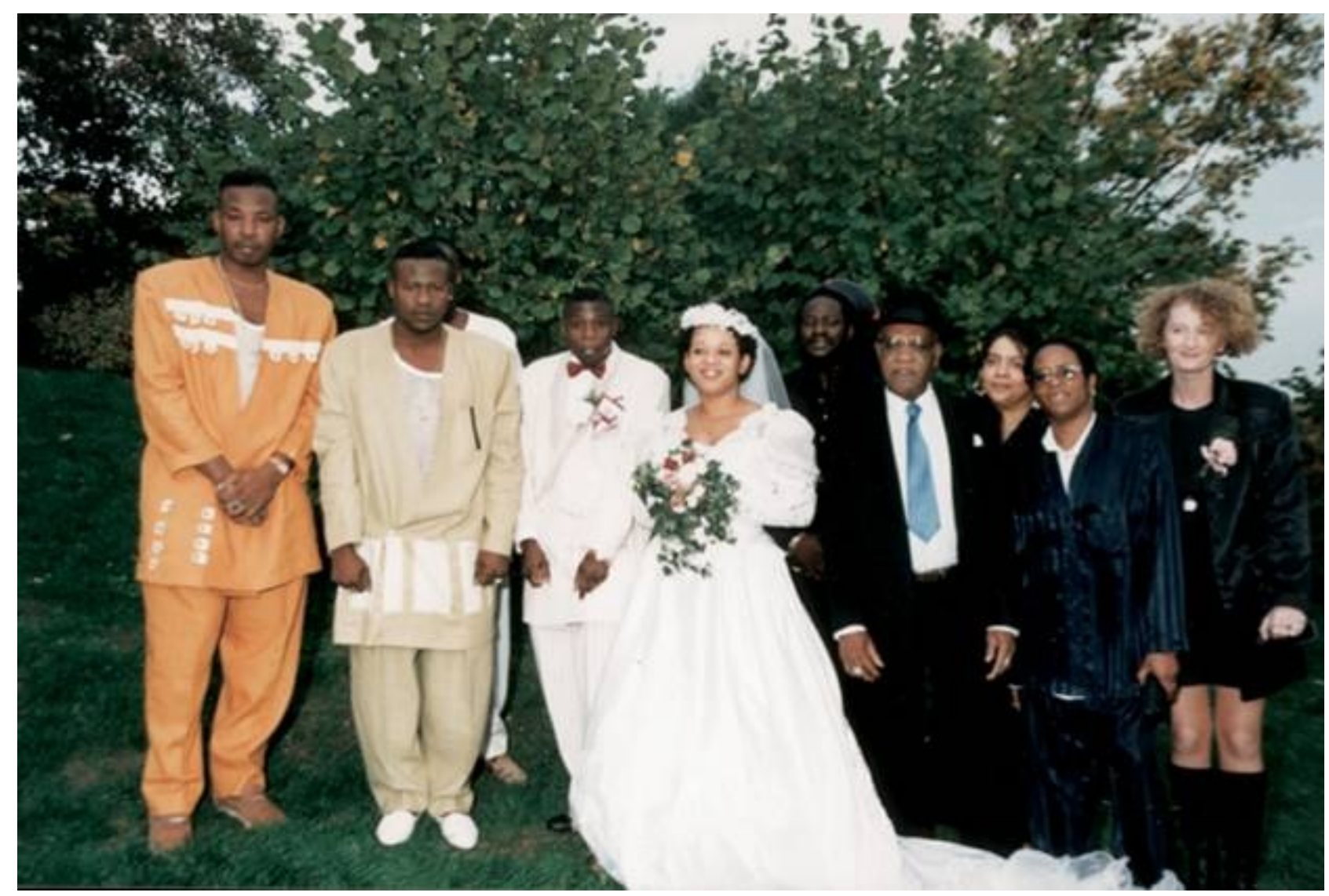

Photo 5. Members of the A family, wedding, Leeds Register Office, October 1995

Taking this photograph, twenty years after the most difficult period, reminded me again of the effects of racialisation and the fragility of relationships between black and white. Several of the men in this photo, recently arrived from Jamaica, moved quickly to hide themselves when they saw my camera, fearing that I was a representative of the British state. Only when the bride assured them that I was 'safe' would they consent to join the group for the photo.

3.2 The changing politics of the Chapeltown area are equally relevant to this analysis of the photographic process. Elsewhere (Farrar 2002b) I have described this as the substitution of the 'racialised revolutionary' practice of the most militant tendencies among the Caribbean population by the reformist politics of all the non-white populations in response to neo-colonial interventions by the city council in the wake of the 1981 uprisings. The council sponsored the professionalisation of some of the leaders of the ethnic organisations, and promoted, by its grant-aid policies, ethnic segmentation. Modernity's unceasing drive towards individualisation (Beck and Beck-Gernsheim 2002), speeded up by Thatcher's neo-liberalism, was a further source of the decline of black radicalism in Chapeltown. The resulting changes in the configurations of ethnic identification - the decline of nationalistic identifications during the 1980s - along with the development of deeper and more personal relationships actually made it much easier for me to take photographs. As radicals of all ethnicities found their political positions and their identities being transformed both by the ageing process and the new configuration of local politics, a certain amount of fluidity entered social relationships which had hitherto been ossified by ideology.

3.3 To explain this a little further, I want to re-visit one aspect of the professional process of taking photographs. Many professionals started their careers as 'photographer's assistants', which seems to have consisted of learning the technical and sometimes aesthetic aspects of the job while carting equipment around, changing and developing films, fetching the coffee, setting up lights and so on. In retrospect, I see that for a white man to cross racialised boundaries and document practices in the multi-ethnic inner city which are hidden from the dominant white gaze, a different type of assistant is needed. This is the person who asks you to come with him to places a white, middle class male would not normally go to. In 1989, Culture T, the subject of Photo 6, asked me to be a DJ on his 'community' (i.e. unlicensed) radio station because I was the only person he knew with a substantial collection of jazz records. 


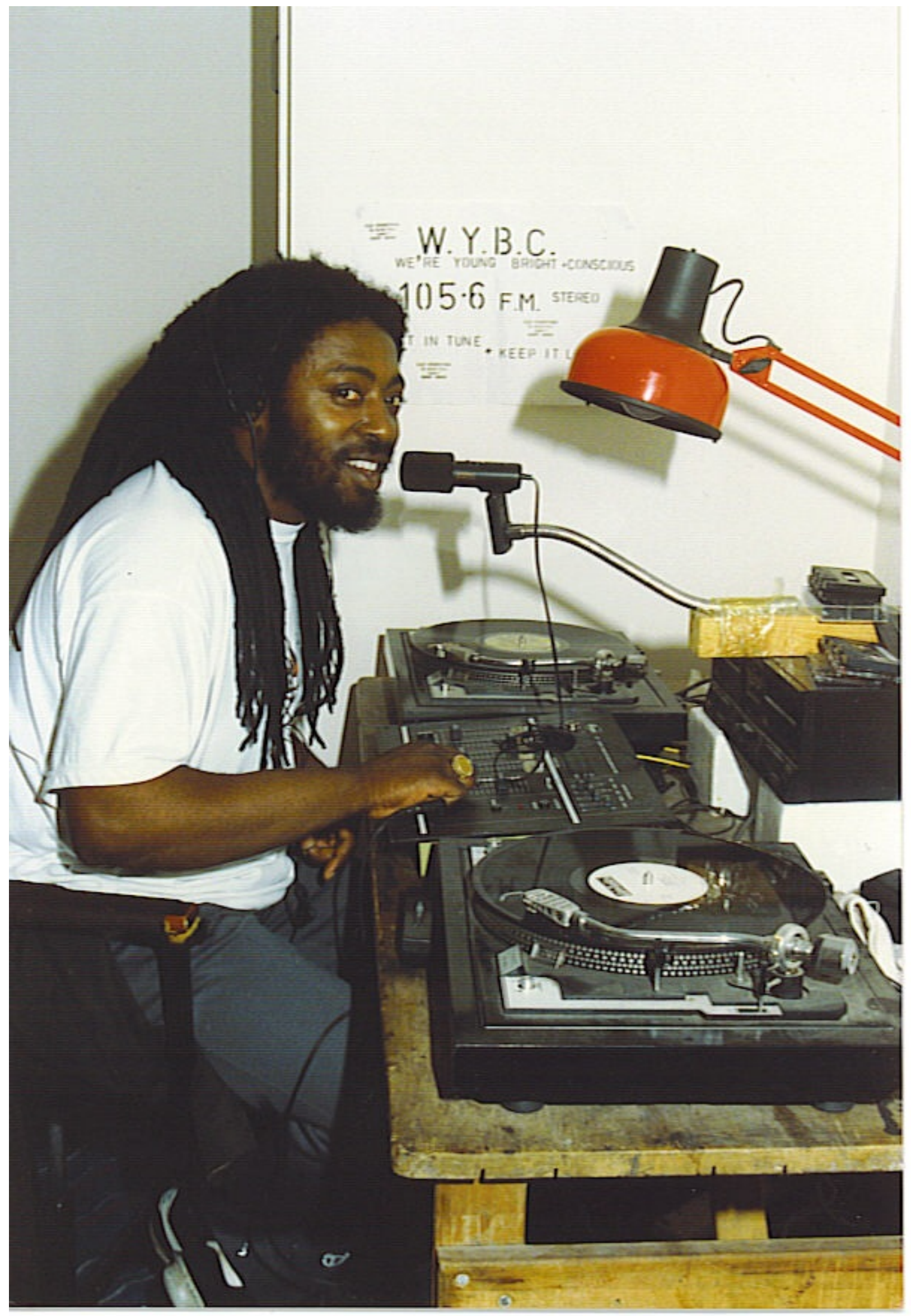

Photo 6. Culture T, at the WYBC studio, Chapeltown, Leeds, September 1989

For the next five years I played on a Sunday morning (all the other DJs, naturally, were asleep) to a mass audience of about 20 jazz aficionados in Chapeltown. His station, WYBC, stood for We Are Young Black and Conscious when the other DJs were broadcasting, and West Yorkshire Broadcasting Corporation when I was on the air. Photo 6, then, documents the make-shift studio in a borrowed flat (September 1989). In his other life as a music promoter, Culture T took me to photograph the Jamaican Reggae singer Nerious Joseph and Stone Roots, the local band that Culture T managed (Photo 7, July 1990). 


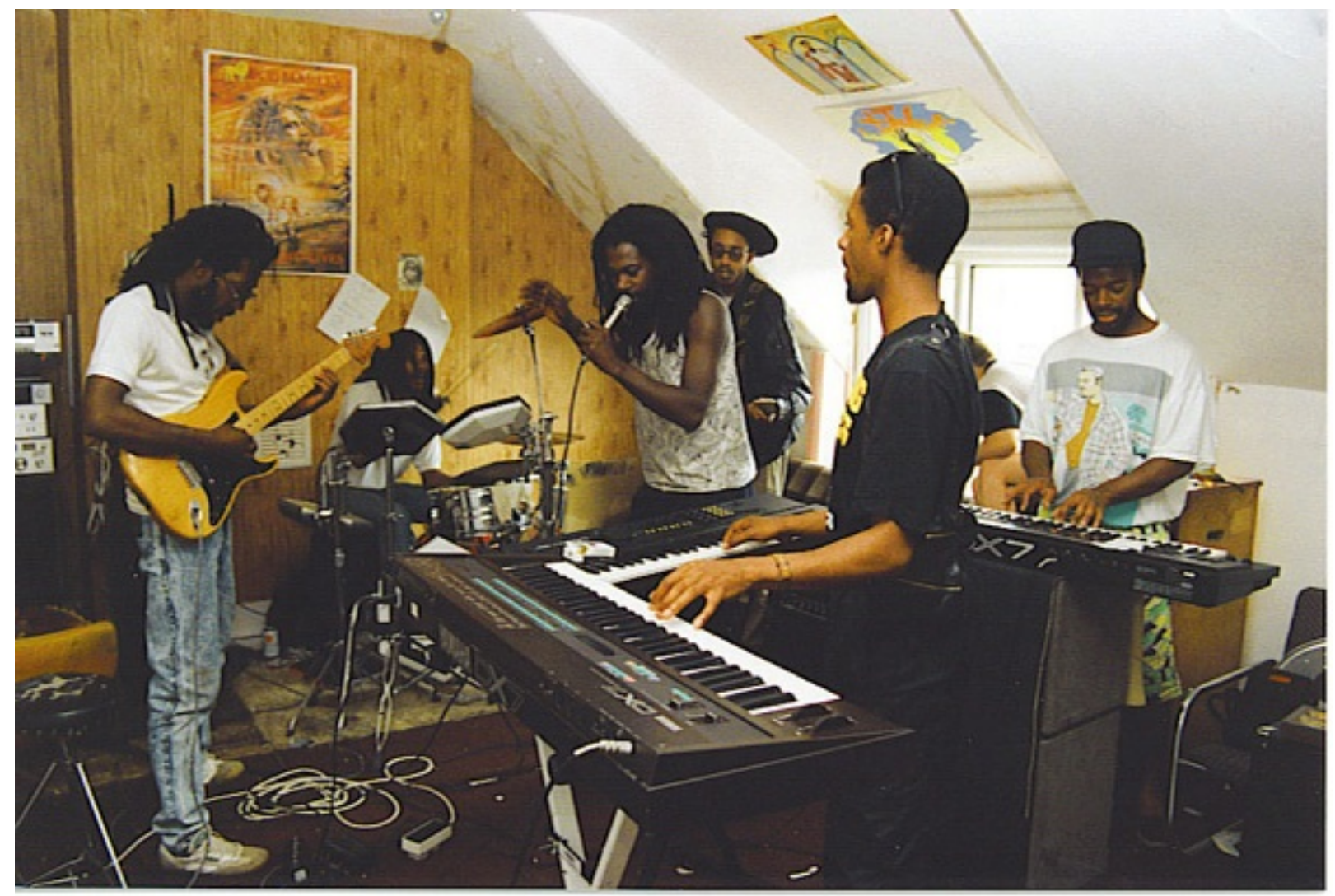

Photo 7. Stone Roots rehearse with Nerious Joseph, Chapeltown, Leeds, July 1990

These photos were to complement the series I had taken for Stone Roots' marketing strategy. There is nothing remarkable about this photo except its setting and its context. The setting is another flat in Chapeltown set aside as a practice space for people who cannot afford commercial studios, and the context is the serious dedication put in by local musicians, with no sponsorship of any kind, to make their way in the music business. Photo 8 (our home, September 1990) illustrates another type of 'photographer's assistant'. It is a birthday snap of a group of 15 year old young women, including our daughter, who have been friends since they met at Primary School, aged five. The girl the middle is the daughter of one of our oldest personal friends in Chapeltown, but the long-lasting relationships we formed with the parents of the other two young black women are purely the result of our daughter's choices as a little girl.

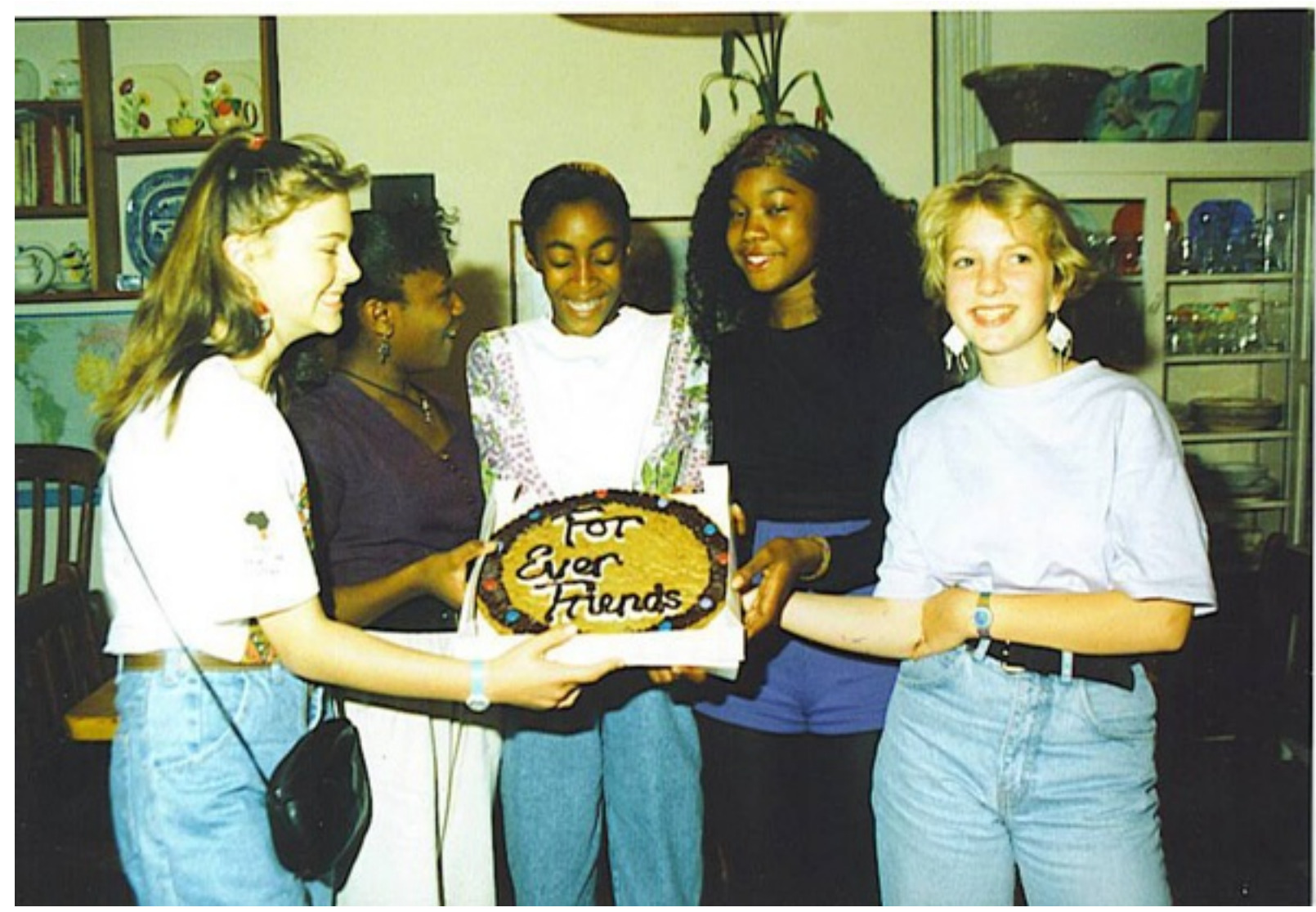


Photo 8. Our daughter Rose, with friends, our home, September 1990

At this point, the camera merely records a set of relationships. It has not been a factor in establishing those relationships - the camera usually came out long after the relationships were established - but those 'near family' relationships have been an essential part of the process of overcoming racialised barriers, and providing access to scenes where those barriers are, at least temporarily, dropped.

3.4 If my photography for most of the 1970s was principally linked to reporting and supporting radical campaigns in the inner city, I now situate my work during the 1980s somewhere between documentary and propaganda. It became a means of recording everyday experience of inner-city life in multi-ethnic Britain. Representation is never politically neutral, and Photos 3 and 4 were overtly placed in the context of political and legal campaigns. But even the photos of weddings, pirate radio studios, rehearsals, birthdays and such like (e.g. Photos 5, 6, 7, 8) contain less obvious ideological messages. In trying to capture the ordinariness of everyday life in the situations in which black and white skinned people interact, these photos aim to disclose to the careful reader the similarities in black and white people's lives, where other writers and photographers aim to emphasise the difference. These photos are carefully staged with the intention of producing an affirming, even celebratory, response in all but the racists among those that view them. The techniques for manipulating this response are simple, but worth spelling out. They are taken in places which are utterly familiar to all modern, urban viewers - places in which the spatial arrangements of trees, instruments, furniture etc are just the same for white people as they are for black. While some viewers might be surprised by the colour of skin and types of hairstyle, several of those people whose appearance might unsettle some white viewers smile broadly, employing the universal sign of welcome and friendship. Finally, two of them (the wedding, Photo 5, and the five young women, Photo 8) straightforwardly depict people with different skin colours in situations in which inter-ethnic harmony can be assumed; if there is any doubt, the script in Photo 8 establishes that as 'fact'. The counter-fact - that families fight and friends fall out - is deliberately excluded in these photos.

3.5 A helpful review of the first draft of this essay ${ }^{[1]}$ pointed out that it has a tendency in places to reproduce a conventional notion of insider/outsider boundaries, and even to postulate a privileged 'insider' account of black life in this neighbourhood. In the spirit of reflexivity in which this essay is written I have to acknowledge and respond to the reviewer's comment. On the insider/outsider point, my intellectual response is akin to the point made earlier on black/white boundaries: while they are transcended in poststructuralism (and in some people's everyday lives), they remain intact in many quarters. Similarly, wherever social life is conducted, an insider/ outsider binary underpins the action - sometimes to be solidly erected, sometimes to be played with, sometimes to be quickly deconstructed. That has been, and remains, my own experience. Emotionally, all these encounters are charged with the knowing/feeling that solid boundaries hurt, like running into a lamp-post hurts; mocking the boundaries might be pleasant or unpleasant; but when boundaries fall away, joyful new experiences become possible. Human photography often visualises the inside/outside boundary: where the subject's face and body posture expresses pleasure, happiness or self-directed desire, the viewer feels that barriers are, in that moment, down. Viewed in this way, I think it should be clear that I cannot claim any particular privilege for my account. To the extent that I become an insider, it is only because people have let me inside, and there are many situations from which I have been, and remain, excluded. (I have, for instance, consistently failed in my attempts to interview the young men - mainly British Muslims - who engaged in violent urban protest in Harehills, the neighbourhood adjacent to Chapeltown, in the summer of 2001 (Farrar 2002a). I have no access to the current generation of youths of African-Caribbean descent who are engaged in the drugs trade in Chapeltown.) Nevertheless, one of the aims of this essay is to show that, under certain circumstances, racialised boundaries between myself and people whose skin colour is different from mine, do mysteriously, and beautifully, disappear.

\section{The Late 1990s: Thinking Photographically and Sociologically}

4.1 I returned to academic sociology in the mid 1990s, picking up the $\mathrm{PhD}$ thesis I had dropped in disgust in 1974. Apart from the pleasures afforded by acquiring a stable, liveable income, I recalled the pleasure that sociological theory had provided, briefly, in the early 1970s. Thanks to the work of Stuart Hall, Zygmunt Bauman, bell hooks and Paul Gilroy I regained my faith that sociological thinking could contribute to emancipation. On completing the thesis I began to realise that my photographic work might be linked to my sociological work. Having employed Henri Lefebvre's (1974/1991) urban sociological theory in explaining the social construction of the locale known as Chapeltown, I realised that his 'production of space' theory contains observations on representation which might usefully be applied to my photography. In particular, Lefebvre's focus on representation seemed to provide an answer to the problems that had always concerned me about both the production of my photos, and their reception. First of all, he suggested that the concept of representation 'supplants the concept of ideology' (Lefebvre 1991 p. 45), because it brings together the ideas contained in the 'long obsolescent notion of ideology' (ibid. p. 44) with those contained in knowledge: 
in 'representation', 'ideology and knowledge are barely distinguishable'. I would argue that documentary photography as a form of representation is a prime example of this blurring: its entrancing quality of naturalness, real-ness, verisimilitude means that the documentary photograph is able quickly to take on the status of factual knowledge, concealing the particular interests of the photographer, the processor and the people who control its dissemination. Although he makes no reference to Lefebvre, Hall (1997) presents a similar case, applying Gramsci and Foucault. But we can derive from Lefebvre further dimensions to an understanding of photography by applying his distinction between representations of space and spaces of representation (Lefebvre 1991pp. 38-46). The former, which he summarises as 'the conceived', refers to the scientific and technical depictions of space which are developed and applied by architects, planners and social engineers. In producing representations (with their phoney verisimilitude) I see myself aligned with the 'conceivers'. Lefebvre's 'spaces of representation' ('the lived' experience of space) is the much messier domain of the images and symbols which people utilise in their everyday lives as they inhabit space. My photographs - often inspiring delighted identifications when they are displayed locally - contribute to this domain. Both of these 'spaces' are understood by Lefebvre to engage in a triadic relationship with 'spatial practice' ('the perceived'), the overall process (from individual, daily routines to the building of cities) by which space is produced. Lefebvre discusses painting as a form of representation in which scientific ideas such as perspective are applied, from the Renaissance onwards, and then subverted in movements such as Cubism, but so far as I know he did not engage with photography. Yet documentary photos can be understood as providing the viewer with an exciting collision of the conceived and the lived. In so far as they contain all the elements of classical perspective, with matter represented realistically, they are taken to be accurate, objective representations of space; but even the dullest scene cannot escape from the viewer's infusion of that photograph with his or her idiosyncratic imaginings. Particularly where photos contain human bodies, viewers read into the photo their whole gamut of desires and hostilities as they pitch their own lived experience alongside or against whatever they imagine the photograph to represent. From this, I might offer a bridge between my personal reflections and memories of the situations in which particular photographs have been produced and Lefebvre's sociological theory: my lived, embodied, emotional experience bumps into the intellectual work both of setting up the photograph and interpreting the print (or the screen image) that emerges later. Because of the changes in my lived experience, I read a photograph taken twenty years ago quite differently from the reading I made of it at the time. Thinking further with Lefebvre, I now begin to see my photographs not so much as documentaries aiming to manipulate 'positive' (i.e. 'anti-racist') responses in the viewer, but as incitements to see beyond the scientific, rational and 'realistic' elements within the photo and plunge into the lived, embodied, fantastic elements of the scenes I depict.

4.2 Emmanuel Levinas provides a further means for reflection, which is part self-reflection, and part sociological rumination (can these be sensibly separated anymore?). Levinas provides a means of theorising a long-held recognition that my most successful photographs - judged in terms of my own feelings of satisfaction when looking at them, and from the reactions of people who see them - were those in which a person, or a group of people, were the predominant subject. I became aware that the best of these photos captured something of the emotional depth of the subjects, and that this resulted at least in part from the warm feelings that the subjects and I had for each other during the process of taking the photographs. This relationship is expressed aesthetically in the most successful photographs. But Levinas would argue that the crucial element here is not the special, personal relationship between me and the subject. According to Levinas, the critical factor is the simple presence of the human face. In one of the most moving of many statements by Levinas on the phenomenology, and the politics, of the face-to-face encounter between humans, he writes:

The presentation of the face puts me in relation with being. The existing of this being . . . is effectuated in the non-postponable urgency with which he $(\mathrm{sic})$ requires a response. The face in its nakedness as a face presents to me the destitution of the poor one and the stranger . . . [who] presents himself as an equal ... It is my responsibility before a face looking at me . . . that constitutes the original fact of fraternity . . Equality is produced where the other commands the same and reveals himself to the same in responsibility ... It cannot be detached from the welcoming of the face... Society must be a fraternal community to be commensurate with the straightforwardness, the primary proximity, in which the face presents itself to my welcome. (Levinas 1988).

4.3 It would clearly be absurd to assume that Levinas believes that every encounter between humans automatically and inevitably evokes this responsibility or produces equality. But it is quite reasonable to assume that the 'original act of fraternity' (and sorority) is conjured up when faces encounter each other in situations in which mutual affirmation is possible - i.e. when material and emotional circumstances do not provoke distancing or fear. More than that, equality between those people is produced when they are able to experience mutual responsibility, on the same terms as each other. Levinas is a philosopher of ethics, and he will not draw back from the 'ought': 'society must be a fraternal community . . $\therefore$. It is the 'welcoming of 
the face' - and of course many situations provoke hostile looks - which provides the sociological and ethical foundation for this community. In statements like these we may find an ethical/political basis for photographing people.

4.4 Faces not only take on particular expressions in specific situations (delight, desire, disaffection etc.), they may also be indelibly damaged by assault, or by contingent or genetic accident. As Goffman (1963/1968) pointed out, faces may be 'spoiled'. (Interestingly, Goffman notes the 'tribal stigma of race, nation and religion' (1968 p. 14), but while he makes quite frequent reference to Jewishness, his references to black people are few and far between.) Faces which have been subjected to stigmatisation continue to 'give off' messages to the person who encounters them which cannot, and should not, be simplistically interpreted. (Goffman's assumption that there is one reading of encounters with the stigmatised is mistaken.) In one of the photos contained in the series displayed here, one subject has a huge and visible scar down the side of her face. Whenever I photograph her, I stand well back and refuse the option now provided by a zoom lens. For many people, the scar signifies the physical violence that she has experienced, and they take this as a summary of who she is. But this is how she spoke of this scar:

The biggest thing to me in life was when I lost my mum, when I was seventeen going on to eighteen, that took my life away, that's why I am the way I am now. Nobody can't say they really know me. They think they know me. They know me with the scars, and that's what they think they can brand me with, but then at the end of the day I know l've got God with me and I can wipe them away, they're nothing (taped interview, 21.8.1996, quoted in Farrar 2002b p. 335).

4.5 Similarly, the face of the person whose skin colour is not white may be read in a myriad of ways by the person she encounters whose skin colour is described as white. One relevant factor is the degree to which skin colour has been racialised by both parties in the encounter. Allowing for the ultimate indeterminacy of the meaning of signs, drawing from Levinas, I now want to see my photographs of people's faces as another type of incitement: an incitement to our ethical responsibility for the Other. These faces, I suggest, call upon us to consider our responsibilities. Many of my photos provide evidence that this responsibility is being enacted in everyday life all the time, despite the brutalisation that surrounds us, threatening to engulf us, and often this responsibility traverses the boundaries that racialisation has erected between us (see photos 9 and 10, in the garden at a wedding party, Chapeltown, July 2001).

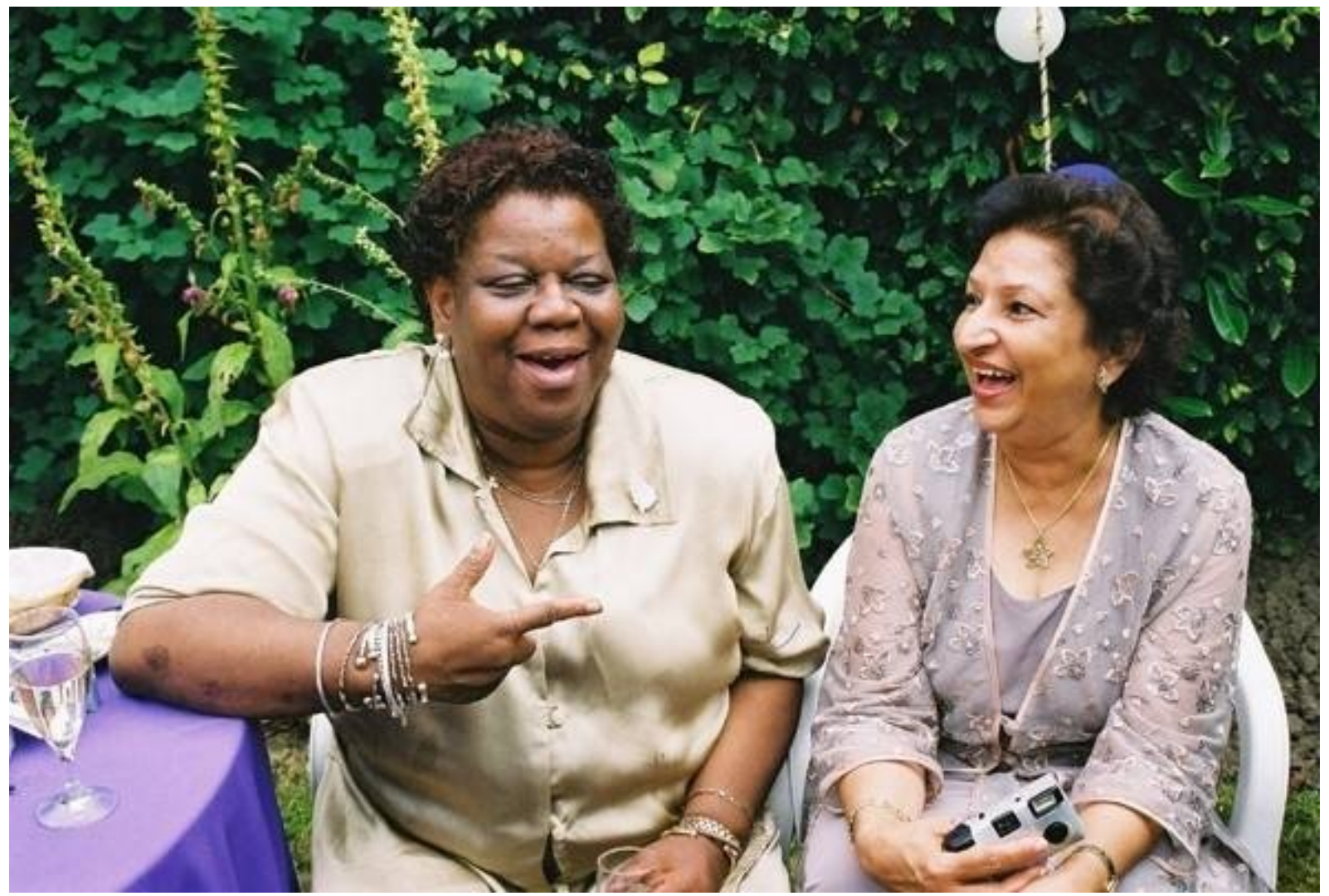

Photo 9. Rick and Nik's wedding party, Chapeltown, July 2001 


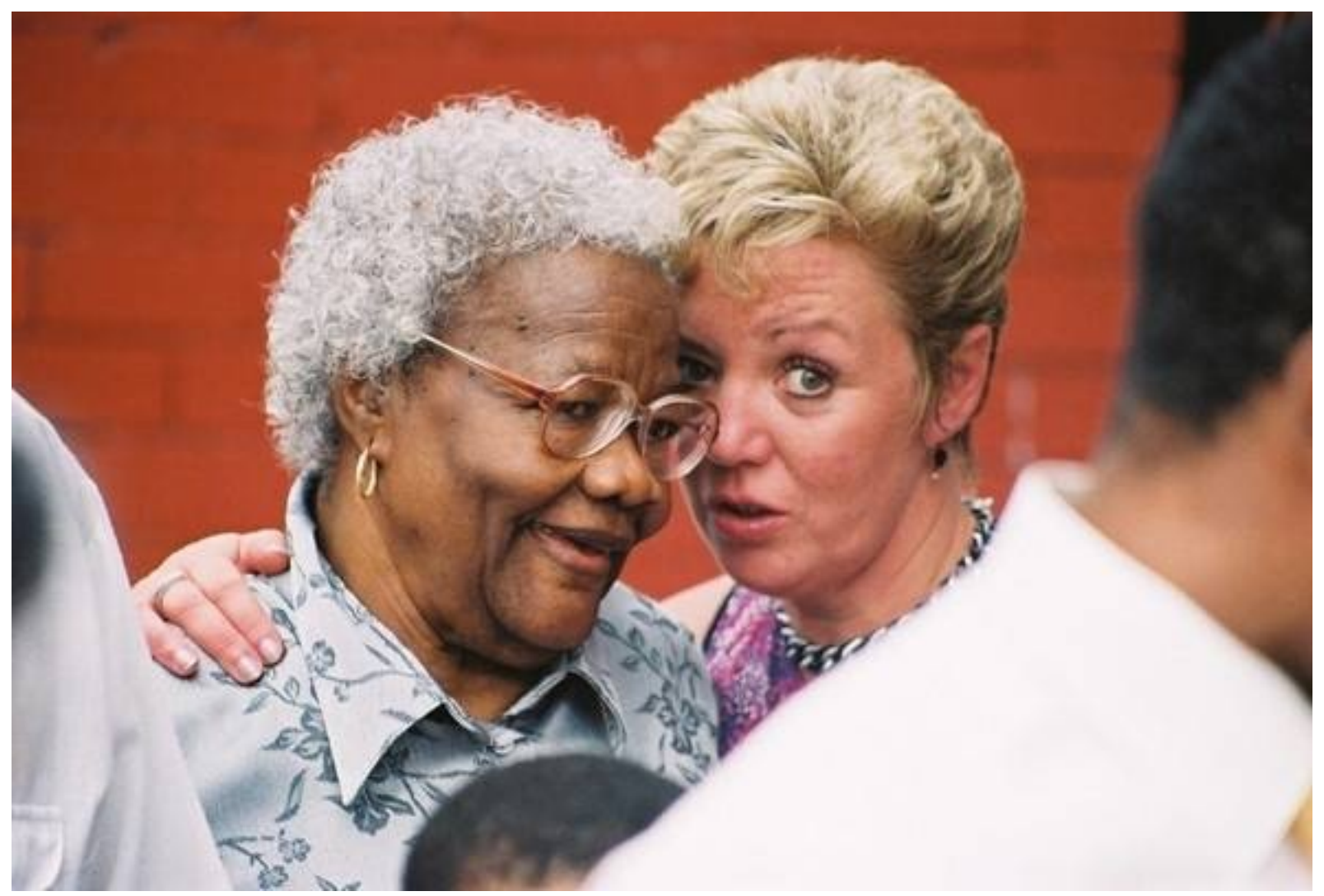

Photo 10. Rick and Nik's wedding party, Chapeltown, July 2001

\section{The New Politics of Representation}

5.1 While there is very good reason to continue in the Twenty-first Century with the straightforward process of taking photos for the purpose of radical political propaganda, the current configuration of the political field requires a different approach from photographers in the over-developed world. Hyper-individualisation in the rich, post-industrial countries has been accompanied by excesses in the fetishisation of bodies. The post1945 diasporic migrations to the rich countries of people originating in Africa, the Caribbean and South and East Asia, intensified today by the migrations of new groups of refugees, has placed extraordinary emphasis on the signifier of skin. The dynamics of racialisation are the least investigated of the defining processes of late modernity, and photography provides one of the tools through which such investigations might take place. It is even more important than ever for photography somehow to represent these bodies without fetishising them; to produce narratives which normalize, rather than racialise; which lower, rather raise, boundaries between humans. My own photographs are presented here with a comforting narrative of the lessening salience of racialised barriers between myself and many of the non-white people of the city of Leeds. But I have emphasised throughout this paper that these are staged events, carefully selected to support this narrative. Since there is no possibility of an objective photography, political intent such as mine is inevitable. But didacticism is counter-productive. My photos should provide, when read through Lefebvre, a complex story of the final indeterminacy of meaning, and a presentation of the possibility for emotional transcendence, beyond the geometry of the image. Read through Levinas, I suggest that the photos with welcoming and friendly faces might be used in the pursuit of ethics of brotherhood and sisterhood, across all arbitrary divides. Here, I suggest, we see the relevance of sociological and philosophical theory to the production and reception of photographs.

5.2 In conclusion, let me return to the original question: is my photographic work part of the problem, or part of the solution? I suggest that, to the extent that these photographs re-configure racialised boundaries they are part of the solution. Allowing for the varying positions from which each photo is apprehended, when the photos in this essay contain within them an unmistakable representation of pleasure and friendship which overcomes the difference that colour is supposed to make, or when they contain faces which evince in the viewer an ethic of responsibility, irrespective of the cultural positions of the subject and the viewer, I claim a politically progressive, but rather small, role for the work I do.

\section{Notes}

${ }^{1}$ Most of the photographs and several of the ideas in this essay were given a trial run at the International Visual Sociology Association's conference in San Francisco, August 2004. I am grateful to Leeds Metropolitan University for financial support to attend this meeting, and to the many people whose papers I 
learned from, and for many stimulating after-hours conversations at the IVSA. I ran the slides again at the staff research conference at Leeds Metropolitan University in September 2004, where I was told (facetiously, I was assured) that a few family snaps hardly constitute research. Some of them were discussed again at a seminar organised by Kayo Obepiyi at the School of Historical and Critical Studies, University of Brighton, where the challenging discussion was most helpful. I am very grateful to the editors and both of the anonymous reviewers for this issue of Sociological Research On-line for their supportive and insightful comments on the first draft of this essay.

\section{References}

BECK, Ulrich and Beck-Gersheim (2002) Individualization London: Sage.

BUCKMAN, Peter (1970) The Limits of Protest, London: Panther.

BUHLE, Paul (1988) C.L.R. James(The Artist as Revolutionary, London: Verso.

CARMICHAEL, Stokely and Hamilton, Charles V (1969) Black Power - The politics of liberation in America, Harmondsworth: Pelican Books.

CAUTE, David (1988) '68 - The year of the barricades, London: Grafton Books.

CLEAVER, Eldridge (1969) Soul on Ice, London: Jonathan Cape

COCKBURN, Alexander and Blackburn, Robin (eds.) Student Power, Harmondsworth: Penguin.

COHN-BENDIT, Danile (1968) Obsolete Communism - The left-wing alternatives, Harmondsworth: Penguin.

CONNOR, Geraldine and Farrar, Max (2004) 'Carnival in Leeds and London, UK: Making New Black British Subjectivities' in Riggio, Milla, C (ed.) (2004) Culture in Action - The Trinidad Experience, London and New York: Routledge

CRICK, Bernard and Robson, William (eds) (1970) Protest and Discontent, Harmondsworth: Penguin.

FARRAR, Max (1981) (aka Paul Holt) 'Riot and Revolution: the Politics of an Inner City', Revolutionary Socialism, the journal of Big Flame Winter 1981-2.

FARRAR, Max (1989) 'The Libertarian Movements of the 1970s', Edinburgh Review No. 82 pp. 58-74.

FARRAR, Max (2002a) 'Sociological observations on the 'riots' in the summer of 2001 - the example of Harehills.' Paper delivered to the British Sociological Association annual conference, University of Leicester, $27^{\text {th }}$ April 2002.

FARRAR, Max (2002b) The Struggle for "Community" in a British Multi-Ethnic Inner City Area - Paradise in the Making, Lewiston, Queenston, Lampeter: Edwin Mellen Press.

FRYER, Peter (1984) Staying Power(The history of black people in Britain, London: Pluto Press.

GOFFMAN, Erving (1963/1968) Stigma - Notes on the management of spoiled identity, London: Penguin.

HALL, Stuart (1997) 'The work of representation' in Hall, Stuart (ed.) (1997) Representation - Cultural representations and signifying practices, London: Sage.

HOWELL, John (1981) 'Big Flame: Resituating socialist strategy and organisation' in Miliband, Ralph and Saville, John (1981) Socialist Register 1981, London: Merlin Press.

JAMES, C.L.R, Lee, Grace C., and Chaulieu, Pierre (1958/1974) Facing Reality, Detroit: Correspondence Publishing Co.

JOHNSON, Linton Kwesi (2002) Mi Revalueshanary Fren, London: Penguin.

LEFEBVRE, Henri (1974/1991) The Production of Space [translated by Donald Nicholson-Smith], Oxford: Blackwell.

LEVINAS, E (1988) 'Useless Suffering' in Bernasconi, R and Woods, D (eds) (1988) The Provocation of Levinas, London: Routledge.

MILES, Robert (1989) Racism, London: Routledge. 
MURJI, Karim and Solomos, John (eds) (2005) Racialization - Studies in Theory and Practice Oxford: Oxford University Press.

NUTTALL, Jeff (1970) Bomb Culture, London: Paladin.

PICKERING, Michael (2001) Stereotyping - The politics of representation, London: Routledge.

RAMDIN, Ron (1987) The Making of the Black Working Class in Britain , Aldershot: Gower Publishing Co.

SHOHAT, Ell and Stam, Robert (1994) Unthinking Eurocentrism - Multiculturalism and the media, London: Routledge.

SIVANANDAN, A. (1982) A Different Hunger(Writings on Black Resistance, London: Pluto Press.

WIDGERY, David (1976) The Left in Britain 1956 - 1968 Harmondsworth: Penguin. 